\title{
Reliability and Validity of the Turkish Adaptation of VITACORA-19 in Patients With Psoriatic Arthritis
}

\author{
Berna TANDER,, ${ }^{1}$ Yasemin ULUS, ${ }^{1}$ Yüksel TERZİ, ${ }^{2}$ Yeliz ZAHİROĞLU, ${ }^{1}$ Hakan KESMEN,,${ }^{1}$ Bayram \\ FARİSOĞULLARI, ${ }^{1}$ Yeşim AKYOL, ${ }^{1}$ Ayhan BILGİCİ, ${ }^{1}$ Ömer KURU ${ }^{1}$ \\ ${ }^{1}$ Department of Physical Medicine and Rehabilitation, Medical Faculty of Ondokuz Mayıs University, Samsun, Turkey \\ ${ }^{2}$ Department of Statistics, Ondokuz Mayıs University, Faculty of Arts and Science, Samsun, Turkey
}

\begin{abstract}
Objectives: This study aims to evaluate the reliability and validity of the Turkish language version of VITACORA-19 (psoriatic arthritis quality of life questionnaire) in patients with psoriatic arthritis.

Patients and methods: The Turkish version of VITACORA-19 questionnaire was obtained after a translation and back translation process. The study sample included 61 PsA patients ( 22 males, 39 females; mean age $46.5 \pm 12.2$ years; range 19 to 71 years). To assess the test-retest reliability of the Turkish VITACORA-19, the questionnaire was reapplied 10 to 15 days after the first interview (interclass correlation coefficient). Cronbach's alpha ( $\alpha$ ) was used to evaluate the internal consistency. VITACORA-19 was compared with visual analog scale for physician and patient global assessments, the Health Assessment Questionnaire, and Nottingham Health Profile for construct validity. The internal structure of VITACORA-19 was examined by factor analysis.

Results: The individual item intraclass correlation coefficient ranged from 0.77 to 0.98 and Cronbach's alpha ranged from 0.77 to 0.98 . The Cronbach's alpha value for whole scale was determined as 0.96 . The Kaiser-Meyer-Olkin measure of sampling adequacy was 0.90, and Bartlett's test of sphericity had a $\mathrm{p}<0.001$. Turkish VITACORA-19 total scores were correlated negatively with Health Assessment Questionnaire, visual analog scale for pain, and Nottingham Health Profile subgroups, and positively with physician and patient global assessments $(p<0.01)$.

Conclusion: Turkish version of VITACORA-19 questionnaire is a reliable and valid measure for health-related quality of life in Turkish patients with psoriatic arthritis.

Keywords: Health-related quality of life; psoriatic arthritis; Turkish version; validity and reliability; VITACORA-19.
\end{abstract}

Psoriatic arthritis (PsA) is a chronic, generally progressing inflammatory disease leading to irreversible joint damage and severe disability.,2 Donmez et al. ${ }^{3}$ detected a hospital-based prevalence of 27.9/100,000 for PsA patients in Turkey. PsA affects patients' life severely in terms of social, economic, and psychological aspects. ${ }^{1,4,5}$

Health-related quality of life (HRQoL) is a helpful tool for emphasizing the importance of the burden caused by musculoskeletal diseases. It should be evaluated as a multidimensional approach covering the physical, mental, and social components associated with an illness or its treatment. 6,7 As a subjective perspective for functioning, HRQoL is used to denote the portion of the quality of life (QoL) which is affected by individual's health status. For chronic diseases, HRQoL has been accepted as an important tool for decision-making in terms of resource allocation, intervention, design, and treatment. ${ }^{8,9}$

Psoriatic arthritis seriously affects QoL. Reduced functional capacity and QoL are expected outcomes of PsA. ${ }^{10-12}$ Self administered Psoriatic Quality of Life (PsQoL) scale was developed to evaluate the QoL of patients with PsA. ${ }^{13}$ A validity study for the Turkish version of PsQoL was performed by Duruöz et al., ${ }^{14}$ who demonstrated PsQoL to be relevant and 
acceptable to respondents, valid, and reliable with proven sensitivity to changes. ${ }^{15,16} \mathrm{HRQ}$ oL is an important outcome for daily practice and evidence based data; however, to our knowledge, limited number of publications are present regarding PsQoL questionnaires in PsA. ${ }^{16-19}$ PsQoL questions social, psychological, and occupational issues but not physical functions. ${ }^{17}$ Some authors pointed out that the questionnaire for PsQoL is not adequate for the evaluation of HRQoL of patients with PsA because this questionnaire does not include questions on basic dermatological clinical picture. ${ }^{16,17,20}$

VITACORA-19 (psoriatic arthritis quality of life questionnaire) is the second diseasespecific patient reported outcome measurement tool to assess HRQoL in patients with PsA. Consequently, several items of the questionnaire are related to PsA-specific problems. ${ }^{20}$ This instrument was developed for English-speaking patients, thus adaptation to other languages/ cultures is needed. Therefore, in this study, we aimed to evaluate the reliability and validity of the Turkish language version of VITACORA-19 questionnaire in patients with PsA.

\section{PATIENTS AND METHODS}

The study was conducted at the Department of Physical Medicine and Rehabilitation of Medical Faculty of Ondokuz Mayıs University between January 2015 and May 2015. The study was approved by the Faculty Ethics Committee. A written informed consent was obtained from each participant. The study was conducted in line with the principals of the Declaration of Helsinki. The study sample included 61 PsA patients (22 males, 39 females; mean age $46.5 \pm 12.2$ years; range 19 to 71 years). Inclusion criteria were fulfilling the classification criteria of $\mathrm{PsA}^{21}$ and being over 18 years of age. Individuals with psychiatric disorders which may affect QoL scores or who were not fluent Turkish speakers were excluded.

All participants were questioned about age, sex, employment status, education level, duration of psoriasis, duration of PsA, current flare up of arthritis, and received treatment for psoriasis. Perceived current health status within the last week was evaluated based on the answers "yes" or "no" given by the patients for the statements "very good", "good", and "fair". Current severity of arthritis perceived by the patients within the last week was evaluated by percentage of the answers "yes" or "no" given for the statements "no", "mild", and "moderate". Height, weight, and body mass index $\left(\mathrm{kg} / \mathrm{m}^{2}\right)$ were measured according to international standards.

Patients were also evaluated by the tender and swollen joint counts and visual analog scale (0-100 $\mathrm{mm})$ for pain. Joints assessed included the distal interphalangeal, proximal interphalangeal, and metacarpophalangeal joints of the hands; the wrist, elbow, shoulder, acromioclavicular, sternoclavicular, temporomandibular, hip, knee, ankle, and midtarsal joints; and the metatarsophalangeal and proximal interphalangeal joints of the feet. C-reactive protein $(\mathrm{mg} / \mathrm{dL})$ level and erythrocyte sedimentation rate $(\mathrm{mm} / \mathrm{h})$ were measured.

VITACORA-19 consists of 19 questions. Each item allows for 5 Likert-like response choices from "always" to "never", and the referred time period is the previous week. Each dimension score ranges from 0 (optimal) to 95. A high score indicates a good QoL. ${ }^{20}$

The validity of VITACORA-19 was assessed by comparing it with Nottingham Health Profile (NHP) and Health Assessment Questionnaire (HAQ). NHP is one of the measures of generic QoL. NHP was developed in the UK in the 1970s for use in population surveys. It has six dimensions of health: physical mobility, pain, sleep, energy, social isolation, and emotional reactions. Patients are asked whether or not each item applies to them. Each dimension score ranges from 0 (optimal) to 100. Higher score indicates more severely compromised QoL. ${ }^{22}$ The Turkish version of NHP was obtained after an accurate translation process, which resulted in a conceptually equivalent version. ${ }^{23}$

Health Assessment Questionnaire was developed to evaluate the functional status of patients with arthritis. ${ }^{24}$ It includes 20 questions in eight categories of functioning: dressing, rising, eating, walking, hygiene, reach, grip, and usual activities. For each item, there is a four-level difficulty scale that is scored from 0 to 3 , representing normal (no difficulty) (0), some difficulty (1), much difficulty (2) and inability to perform (3). The highest component score in each 
category determines the score for the category, unless aids or devices are required. The possible score ranges from 0 to 3 . Kucukdeveci et al. ${ }^{25}$ adapted the HAQ to the Turkish language and proved its validity.

All subjects were reevaluated two weeks later using an interclass correlation coefficient. In the second examination, physician and patient global assessments, HAQ, NHP, and VITACORA-19 were asked again for test-retest evaluation.

VITACORA-19 was translated into Turkish by three Turkish medical doctors who were proficient in English. Discrepancies in initial translations were addressed with the assistance of a fourth independent translator. The Turkish version of VITACORA-19 was then translated back into English by 2 English-speaking language specialists who were blinded to the original scale and the objective of the study. The differences between translated versions were evaluated, and a satisfactory compliance with the original scale was achieved by consensus of the translators. Firstly, 10 patients completed the questionnaire and were asked whether or not they could understand all items of Turkish VITACORA-19. None of the patients in this initial group reported any problem regarding any item of VITACORA-19. Then, the 61 patients who constituted the study group completed VITACORA-19 Scale.

\section{Statistical analysis}

All data were analyzed with IBM SPSS Statistics for Windows, Version 20.0 software program (IBM Corporation, Armonk, NY, USA). Descriptive statistics were used to characterize the sample. The Kolmogorov Smirnov test was used to analyze normal distribution assumption of the quantitative outcomes and all parameters were not normally distributed. Non-parametric statistical tests were used because of the ordinal nature of the outcome measures. Nonparametric tests for independent samples (the Mann-Whitney $\mathrm{U}$ test for two groups or the Kruskal-Wallis one-way analysis of variance for three or more groups) were used to test differences in VITACORA-19 scores between groups. For group comparison, Kruskal-Wallis test with the Bonferroni correction was used for multiple comparisons of continuous variables.

Internal reliability of VITACORA-19 was evaluated by calculating the Cronbach's alpha coefficient for the whole scale. Test-retest reliability was assessed by the intraclass correlation coefficient (ICC) between scores obtained in the main survey and follow-up. For test-retest reliability assessment, 61 patients were assessed twice with a two-week interval.

Construct validity was evaluated by exploratory factor analysis. The internal structure of VITACORA-19 was examined by factor analysis,

\begin{tabular}{|lccc|}
\hline \multicolumn{2}{|l}{ Table 1. Characteristics of the patients ( $\mathrm{n}=61)$} & & \\
\hline Variable & Mean $\pm \mathrm{SD}$ & Median & Range (Min-Max) \\
\hline Age (years) & $46.5 \pm 12.2$ & 46.0 & $19-71$ \\
Body mass index $\left(\mathrm{kg} / \mathrm{m}^{2}\right)$ & $29.2 \pm 4.2$ & 29.0 & $22-42$ \\
Psoriasis duration (years) & $15.3 \pm 11.6$ & 10.0 & $2-50$ \\
Psoriathic arthritis duration (years) & $10.6 \pm 8.5$ & 8.5 & $2-48$ \\
Swollen joint count & $0.5 \pm 1.5$ & 0.0 & $0-10$ \\
Tender joint count & $1.7 \pm 3.0$ & 0.0 & $0-17$ \\
Erythrocyte sedimentation rate $(\mathrm{mm} / \mathrm{h})$ & $17.9 \pm 13.1$ & 14.0 & $3-60$ \\
C-reactive protein (mg/dL) & $4.0 \pm 4.8$ & 2.0 & $1-28$ \\
Patient pain (visual analog scale) & $45.7 \pm 30.6$ & 50.0 & $0-100$ \\
Health assessment questionnaire & $0.4 \pm 0.5$ & 0.1 & $0-3$ \\
VITACORA-19 & $66.9 \pm 20.2$ & 68.0 & $23-95$ \\
Nottingham Health Profile & & & \\
Energy level & $48.5 \pm 41.4$ & 39.2 & $0-100$ \\
Pain & $42.2 \pm 35.9$ & 38.2 & $0-100$ \\
Emotional reactions & $33.6 \pm 35.2$ & 23.7 & $0-100$ \\
Sleep & $33.4 \pm 36.7$ & 16.1 & $0-100$ \\
Social isolation & $23.5 \pm 36.7$ & 0.0 & $0-100$ \\
Physical mobility & $28.2 \pm 26.2$ & 22.0 & $0-100$ \\
\hline SD: Standard deviation; Min: Minimum; Max: Maximum; VITACORA-19: Psoriatic arthritis quality of life questionnaire. \\
\hline
\end{tabular}


first by using principal component analysis with Varimax rotation, then by using oblique rotation to assess inter-correlation between factors, and finally by specifying a single factor solution to determine the unity of the scale. The KaiserMeyer-Olkin (KMO) test was performed to evaluate sample adequacy. The number of components was determined according to the eigenvalue.

Convergent validity was assessed by examining the correlation between VITACORA-19 and other parameters. Correlation was assessed by Spearman's correlation analysis. $\mathrm{P}$ value of less than 0.05 was considered as statistically significant.

\section{RESULTS}

Demographic and disease-related data of the patients are given in Table 1. The Turkish VITACORA-19 scores were significantly higher in male subjects than females, $(p<0.001)$, in secondary education $(p<0.05)$, in subjects who had not perceived current severity of arthritis as mild $(p<0.05)$, and in subjects who had perceived current health status as very good $(p<0.001)$. Patients reporting a flare of their arthritis also had significantly lower scores in VITACORA-19 compared to patients without a flare $(p<0.05)$ (Table 2). There was no statistically significant difference in Turkish VITACORA-19 scores between married and employed subjects and in subjects who were on treatment for psoriasis (p>0.05) (Table 2).

The individual item ICC ranged from 0.77 to 0.98 and Cronbach's alpha value ranged from 0.77 to 0.98 . The Cronbach's alpha value of the whole scale was determined as 0.96 (Table 3).

Test-retest reliability of the Turkish version of VITACORA-19 was 0.96, demonstrating very good reproducibility (Table 4).

Factor analysis of the 19 items in VITACORA-19 revealed two factors above eigenvalue of 1 , which were more prominent (Table 5). Each item was represented in factor analysis. At the end of the

\begin{tabular}{|c|c|c|c|c|}
\hline & Mean \pm SD & Median & Min-Max & $p$ \\
\hline \multicolumn{5}{|l|}{ Sex } \\
\hline Female & $61.7 \pm 20.7$ & 62.0 & 23-94 & \multirow{2}{*}{$0.008^{* *}$} \\
\hline Male & $76.1 \pm 16.0$ & 79.0 & $45-95$ & \\
\hline \multicolumn{5}{|l|}{ Marital status } \\
\hline Married & $67.5 \pm 20.7$ & 69.0 & $23-95$ & \multirow{2}{*}{0.526} \\
\hline Other & $63.9 \pm 18.5$ & 65.0 & $33-91$ & \\
\hline \multicolumn{5}{|l|}{ Education } \\
\hline Primary education & $61.0 \pm 20.7$ & 62.0 & $23-94$ & \multirow{2}{*}{$0.017^{*}$} \\
\hline Secondary education + college & $76.5 \pm 21.0$ & 83.0 & $47-93$ & \\
\hline \multicolumn{5}{|l|}{ Employment status } \\
\hline Housewife & $62.4 \pm 21.8$ & 62.5 & $24-94$ & \multirow{5}{*}{0.379} \\
\hline Retired & $59.7 \pm 12.8$ & 65.0 & $45-69$ & \\
\hline Working & $69.7 \pm 17.5$ & 69.0 & $47-95$ & \\
\hline Officer & $77.0 \pm 10.0$ & 77.0 & $67-87$ & \\
\hline Other & $72.6 \pm 19.7$ & 80.0 & $23-94$ & \\
\hline \multicolumn{5}{|l|}{ Using treatment for psoriasis } \\
\hline Yes & $58.8 \pm 11.6$ & 58.0 & $45-76$ & \multirow{2}{*}{0.218} \\
\hline No & $67.7 \pm 20.8$ & 69.0 & $23-72$ & \\
\hline \multicolumn{5}{|l|}{ Current flare up of arthritis } \\
\hline Yes & $57.6 \pm 18.6$ & 53.5 & 24-93 & \multirow{2}{*}{$0.027^{*}$} \\
\hline No & $69.6 \pm 20.1$ & 74.0 & $23-95$ & \\
\hline \multicolumn{5}{|l|}{ Perceived current severity of arthritis } \\
\hline No & $73.1 \pm 19.9$ & 80.0 & $23-95$ & \multirow{3}{*}{$0.011^{*}$} \\
\hline Mild & $62.4 \pm 17.8$ & 63.0 & $24-93$ & \\
\hline Moderate & $50.7 \pm 17.8$ & 47.0 & $24-81$ & \\
\hline \multicolumn{5}{|l|}{ Perceived current health status } \\
\hline Very good & $76.9 \pm 17.2$ & 81.0 & $23-95$ & \multirow{3}{*}{$0.001^{* * *}$} \\
\hline Good & $60.7 \pm 18.6$ & 59.5 & $24-93$ & \\
\hline Fair & $44.8 \pm 12.4$ & 45.0 & $24-63$ & \\
\hline
\end{tabular}


Table 3. Internal consistency and test-retest reliability of Turkish VITACORA-19

\begin{tabular}{lcc}
\hline VITACORA-19 questions & ICC & Cronbach's alpha \\
\hline $1^{\text {st }}$ question & 0.91 & 0.92 \\
$2^{\text {nd }}$ question & 0.96 & 0.96 \\
$3^{\text {rd }}$ question & 0.93 & 0.93 \\
$4^{\text {th }}$ question & 0.96 & 0.96 \\
$5^{\text {th }}$ question & 0.93 & 0.93 \\
$6^{\text {th }}$ question & 0.95 & 0.95 \\
$7^{\text {th }}$ question & 0.95 & 0.95 \\
$8^{\text {th }}$ question & 0.93 & 0.93 \\
$9^{\text {th }}$ question & 0.92 & 0.92 \\
$10^{\text {th }}$ question & 0.96 & 0.96 \\
$11^{\text {th }}$ question & 0.94 & 0.94 \\
$12^{\text {th }}$ question & 0.94 & 0.93 \\
$13^{\text {th }}$ question & 0.98 & 0.98 \\
$14^{\text {th }}$ question & 0.96 & 0.96 \\
$15^{\text {th }}$ question & 0.96 & 0.96 \\
$16^{\text {th }}$ question & 0.77 & 0.77 \\
$17^{\text {th }}$ question & 0.97 & 0.97 \\
$18^{\text {th }}$ question & 0.94 & 0.94 \\
$19^{\text {th }}$ question & 0.95 & 0.95 \\
Total & & 0.96 \\
VITACORA-19: Psoriatic arthritis quality of life questionnaire; ICC: Intraclass $^{\text {correlation coefficient. }}$ & \\
\hline
\end{tabular}

analysis, KMO value was determined as 0.90, which was observed to be a suitable value for the analysis of essential variables. Similarly, Bartlett's test of sphericity results $(p<0.001)$ suggested that data were inter-related and suitable for factor analysis.

Total matrix variance was $66.24 \%$ for both factors (factor 1, 59.74\%; factor 2, 6.50\%). Tasks related to activities including moods were listed under factor 2; whereas tasks related to functions were listed under factor 1 . Finally, the construct validity of our translated questionnaire was evaluated as satisfactory (Table 5).

Construct validity (comparison of VITACORA-19 with the other scales used for evaluation of PsA) is given in Table 6. The Turkish version of VITACORA-19 scores negatively correlated with the HAQ $(r=-0.60)$ and the most significant negative correlation was obtained with NHP emotional reactions $(r=-0.72)$ and NHP pain $(r=-0.68)(p<0.01)$ (Table 6). There was also a positive correlation between VITACORA-19 scores and patient global assessment $(r=0.44)$ and physician global assessment $(r=0.48) \quad(p<0.01)$ (Table 6). Correlation of VITACORA-19 with the other subgroups and scales was relatively similar (Table 6).

\section{DISCUSSION}

Investigations on QoL in rheumatic diseases have extensively increased in last decades. The general consensus to recommend a core set of six domains for PsA was set at Outcome Measures in Rheumatology Clinical Trials 8 and HRQoL was one of these. ${ }^{26}$ There are studies highlighting that QoL has been negatively affected in patients with PsA. However, in these studies, specific QoL scales have not been used. The patient-perceived effect of PsA has been usually assessed through generic questionnaires such as the HAQ or short form 36. ${ }^{10-12,27}$ VITACORA-19 disease-specific instrument has been developed to evaluate HRQoL in patients with PsA and the objective was to develop a questionnaire to calculate a score reflecting the effect of PsA based on patients' perspectives.

Cronbach's alpha coefficient providing us with internal consistency of the scale tested where values over 0.80 are accepted as a higher index of consistency. ${ }^{28}$ In this study, the analysis of internal validity of the Turkish VITACORA-19 revealed that the scale items presented adequate internal consistency (alpha=0.96). In the original study by Torre-Alonso et al., ${ }^{20}$ VITACORA-19 showed high internal consistency (Cronbach's alpha $=0.95$ ) in PsA patients. In addition, individual items in the Turkish VITACORA-19 ranged between 0.77 and 0.98. Considering these results, in the current study, the internal consistency of the Turkish VITACORA-19 is even higher than the original test by Torre-Alonso et al. ${ }^{20}$

Table 4. Internal consistency and test-retest reliability of VITACORA-19

\begin{tabular}{lccccc}
\hline Median & Range & Cronbach's alpha & $\begin{array}{c}\text { ICC } \\
(95 \% \mathrm{CI})\end{array}$ & $\begin{array}{c}\text { Test-retest reliability } \\
(95 \% \mathrm{CI})\end{array}$ \\
\hline $1^{\text {st }}$ assessment & 3.6 & $1-5$ & 0.87 & $0.85(0.78-0.90)$ & $0.91(0.85-0.94)$ \\
$2^{\text {nd }}$ assessment & 3.6 & $1-5$ & 0.96 & $0.96(0.94-0.97)$ & $0.91(0.85-0.94)$ \\
\hline VITACORA-19: Psoriatic arthritis quality of life questionnaire; ICC: Intraclass correlation coefficient; CI: Confidence interval.
\end{tabular}


Table 5. Results of factor analysis of each Turkish VITACORA-19 item

\begin{tabular}{|c|c|c|c|c|}
\hline \multirow[t]{2}{*}{ Items } & \multirow[t]{2}{*}{ Indicators } & \multicolumn{2}{|c|}{ Factorial load } & \multirow[t]{2}{*}{ Communality } \\
\hline & & Factor 1 & Factor 2 & \\
\hline Item 1 & Limited mobility conditioned my life & 0.64 & 0.43 & 0.59 \\
\hline Item 2 & Takes me a long time to recover from any physical effort & 0.65 & 0.40 & 0.58 \\
\hline Item 3 & It was difficult to change my position in bed (e.g., roll over) & 0.74 & 0.32 & 0.65 \\
\hline Item 4 & My physical strength diminished & 0.82 & 0.29 & 0.76 \\
\hline Item 5 & I was unmotivated, not in the mood of doing anything & 0.56 & 0.66 & 0.75 \\
\hline Item 6 & Due to my exhaustion, I was sad and sorrowful & 0.66 & 0.56 & 0.75 \\
\hline Item 7 & My mood was affected by illness pain & 0.63 & 0.61 & 0.77 \\
\hline Item 8 & I was afraid of pain & 0.63 & 0.54 & 0.69 \\
\hline Item 9 & $\begin{array}{l}\text { I was worried about being dependent on third parties because of } \\
\text { signs and symptoms }\end{array}$ & 0.63 & 0.62 & 0.78 \\
\hline Item 10 & I felt desperate because of symptoms' pain & 0.59 & 0.61 & 0.71 \\
\hline Item 11 & I avoid meeting people & 0.53 & 0.68 & 0.74 \\
\hline Item 12 & $\begin{array}{l}\text { My usual work/non-employment activities (including housework) } \\
\text { performance went down }\end{array}$ & 0.61 & 0.41 & 0.54 \\
\hline Item 13 & I was afraid of lose my job after asking for a sick leave & 0.02 & 0.75 & 0.57 \\
\hline Item 14 & People shun me because of my skin appearance & 0.16 & 0.63 & 0.42 \\
\hline Item 15 & $\begin{array}{l}\text { I had difficulties doing some manual activities (e.g., grab something, } \\
\text { driving, cooking, use computer...) }\end{array}$ & 0.68 & 0.27 & 0.53 \\
\hline Item 16 & My pain woke me up in the middle of the night, not allowing me to rest & 0.75 & 0.32 & 0.67 \\
\hline Item 17 & Pain affected me the most & 0.88 & 0.06 & 0.77 \\
\hline Item 18 & $\begin{array}{l}\text { Inflammation and joint discomfort (e.g., ankle, knee, wrist, fingers...) } \\
\text { affected me the most }\end{array}$ & 0.85 & 0.21 & 0.77 \\
\hline Item 19 & $\begin{array}{l}\text { I was worried about the future evolution of my illness (e.g., needing a } \\
\text { cane or crutches...) }\end{array}$ & 0.73 & 0.23 & 0.58 \\
\hline \multicolumn{2}{|c|}{ Engein values (eigenvalue) } & 11.35 & 1.24 & 12.59 \\
\hline \multicolumn{2}{|c|}{ Explained variance (\%) } & 59.74 & 6.50 & 66.24 \\
\hline \multicolumn{2}{|c|}{ Cronbach's alpha } & 0.955 & 0.855 & \\
\hline
\end{tabular}

Test-retest reliability is used to assess the consistency of a measure from one time to another. This value was estimated using ICCs. ${ }^{29}$ In the original study by Torre-Alonso et al., ${ }^{20}$ testretest reliability of VITACORA-19 on PsA patient population was high $(\mathrm{ICC}=0.94)$. Consistent with the original study, the individual item testretest coefficient in our study was found to range from 0.77 to 0.98 , which proved its test-retest reliability. Moreover, good test-retest reliability

Table 6. Comparison of VITACORA-19 with other scales

\begin{tabular}{lc}
\hline & \multicolumn{2}{c}{ VITACORA-19 scores } \\
\cline { 2 - 2 } Health assessment questionnaire & $\mathrm{r}$ \\
Nottingham health profile energy level & $-0.60^{*}$ \\
Nottingham health profile pain & $-0.62^{*}$ \\
Nottingham health profile energy level & $-0.68^{*}$ \\
Nottingham health profile sleep & $-0.72^{*}$ \\
Nottingham health profile social isolation & $-0.54^{*}$ \\
Nottingham health profile physical mobility & $-0.65^{*}$ \\
Pain-visual analog scale & $-0.56^{*}$ \\
\hline VITACORA-19: Psoriatic arthritis quality of life questionnaire; ${ }^{*} \mathrm{p}<0.01$. \\
\hline
\end{tabular}

(ICC $=0.96)$ indicates low measurement error for the questionnaire.

Factor analysis is a collection of methods used to examine how underlying constructs influence the responses on a number of measured variables. ${ }^{30}$ The internal structure of the original VITACORA-19 scale was not examined by factor analysis. ${ }^{20}$ The Bartlett's test value was determined before the assessment of factor construct and found to be suitable for factor analysis $(p=0.001)$. The $\mathrm{KMO}$ is used to compare an observed correlation coefficient and the partial correlation coefficient. In this study, KMO value was 0.90 , which may be considered adequate. In the present study, items $5,10,11,13$, and 14, which were related to mood of patients, were included under factor 2 .

Convergent validity was assessed by reviewing the magnitude and direction of the correlation of Turkish VITACORA-19 scores to other performances or scores on other measures. In the current study, there was also a negative correlation between VITACORA-19 
scores and HAQ, NHP, and visual analog scale for pain scores. Some authors found a significant correlation between PsQoL and HAQ scores. ${ }^{16,18}$ This result indicated that higher VITACORA-19 scores were associated with low disease severity and low pain score. Pain may interfere with the activities related to daily life and thus cause poor functional status and diminished QoL. Similar to our study, McKenna et al. ${ }^{13}$ and Billing et al. ${ }^{19}$ reported a significant correlation between subgroups of NHP and PsQoL scores. Thus, we can consider the Turkish version of VITACORA-19 as a questionnaire that evaluates the QoL of PsA patients multi-dimensionally.

Marital and employment statuses and receiving psoriasis treatment had no significant influence on VITACORA-19 scores. Male patients and those with higher education levels had high VITACORA-19 scores. In the original study by Torre-Alonso et al., the effects of demographic data (sex, marital, employment and educational statuses) on VITACORA-19 had not been assessed. ${ }^{20}$ McKenna et al. ${ }^{13}$ demonstrated no influence of sex or marital status on PsQoL. As in our study, they also showed no effect of the presence of psoriasis treatment on PsQoL. ${ }^{13}$ In the study by Wink et al., ${ }^{18}$ the male patients had higher PsQoL scores, as in our study. Similar to the previous studies, patients who do not perceived current severity of arthritis as mild or those who had no flare of arthritis had higher VITACORA-19 score indicating that presence and severity of arthritis are among the main parameters determining the level of HRQoL. ${ }^{13,18,19}$ As expected, our study has shown that excellent perception of health status is an indicator for higher QoL, as the original study pointed out. ${ }^{20}$ We have demonstrated that Turkish version of VITACORA-19 was able to distinguish the difference between perceived severity of arthritis and self-evaluated overall health status among patients.

In conclusion, the findings of this study confirm that Turkish VITACORA-19 has good reliability and validity as a measure of QoL in PsA patient population in Turkey and may be a valid questionnaire for the assessment of QoL both in research and clinical practice.

\section{Declaration of conflicting interests}

The authors declared no conflicts of interest with respect to the authorship and/or publication of this article.

\section{Funding}

The authors received no financial support for the research and/or authorship of this article.

\section{REFERENCES}

1. Duarte GV, Faillace C, Freire de Carvalho J. Psoriatic arthritis. Best Pract Res Clin Rheumatol 2012;26:14756.

2. Gladman DD, Antoni C, Mease P, Clegg DO, Nash P. Psoriatic arthritis: epidemiology, clinical features, course, and outcome. Ann Rheum Dis 2005;64:14-7.

3. Dönmez S, Pamuk ÖN, Akker M, Ak R. Clinical features and types of articular involvement in patients with psoriatic arthritis. Clin Rheumatol 2015;34:1091-6.

4. Lee S, Mendelsohn A, Sarnes E. The burden of psoriatic arthritis: a literature review from a global health systems perspective. P T 2010;35:680-9.

5. Edson-Heredia E, Zhu B, Guo J, Maeda-Chubachi T, Lebwohl M. Disease burden and quality of life in psoriasis patients with and without comorbid psoriatic arthritis: results from National Psoriasis Foundation panel surveys. Cutis 2015;95:173-8.

6. Wilson IB, Cleary PD. Linking clinical variables with health-related quality of life. A conceptual model of patient outcomes. JAMA 1995;273:59-65.

7. Stucki G, Boonen A, Tugwell P, Cieza A, Boers M. The World Health Organisation International Classification of Functioning, Disability and Health: a conceptual model and interface for the OMERACT process. J Rheumatol 2007;34:600-6.

8. Cieza A, Stucki G. Content comparison of healthrelated quality of life (HRQOL) instruments based on the international classification of functioning, disability and health (ICF). Qual Life Res 2005;14:1225-37.

9. Laas K, Roine R, Räsänen P, Sintonen H, Leirisalo-Repo M. Health-related quality of life in patients with common rheumatic diseases referred to a university clinic. Rheumatol Int 2009;29:267-73.

10. Husted JA, Gladman DD, Farewell VT, Long JA, Cook RJ. Validating the SF-36 health survey questionnaire in patients with psoriatic arthritis. J Rheumatol 1997;24:511-7.

11. Zachariae $\mathrm{H}$, Zachariae R, Blomqvist $\mathrm{K}$, Davidsson $\mathrm{S}$, Molin L, Mørk C, et al. Quality of life and prevalence of arthritis reported by 5,795 members of the Nordic Psoriasis Associations. Data from the Nordic Quality of Life Study. Acta Derm Venereol 2002;82:108-13.

12. Rosen CF, Mussani F, Chandran V, Eder L, Thavaneswaran A, Gladman DD. Patients with psoriatic arthritis have worse quality of life than those with psoriasis alone. Rheumatology (Oxford) 2012;51:571-6.

13. McKenna SP, Doward LC, Whalley D, Tennant A, Emery P, Veale DJ. Development of the PsAQoL: a quality of life instrument specific to psoriatic arthritis. Ann Rheum Dis 2004;63:162-9. 
14. Duruoz MT, Nas K, Ozgocmen S, Cerrahoglu L, Cevik R, Kosan $\mathrm{U}$, et al. Translation and validation of the Turkish version of the psoriatic arthritis quality of life questionnaire (PSAQOL). Ann Rheum Dis 2010;69:699.

15. Healy PJ, Helliwell PS. Psoriatic arthritis quality of life instrument: an assessment of sensitivity and response to change. J Rheumatol 2008;35:1359-61.

16. Brodszky V, Péntek M, Bálint PV, Géher P, Hajdu O, Hodinka L, et al. Comparison of the Psoriatic Arthritis Quality of Life (PsAQoL) questionnaire, the functional status (HAQ) and utility (EQ-5D) measures in psoriatic arthritis: results from a cross-sectional survey. Scand $\mathrm{J}$ Rheumatol 2010;39:303-9.

17. Tezel N, Yilmaz Tasdelen O, Bodur H, Gul U, Kulcu Cakmak S, Oguz ID, et al. Is the health-related quality of life and functional status of patients with psoriatic arthritis worse than that of patients with psoriasis alone? Int $\mathrm{J}$ Rheum Dis 2015;18:63-9.

18. Wink F, Arends S, McKenna SP, Houtman PM, Brouwer E, Spoorenberg A. Validity and reliability of the Dutch adaptation of the Psoriatic Arthritis Quality of Life (PsAQoL) Questionnaire. PLoS One 2013;8:55912.

19. Billing E, McKenna SP, Staun M, Lindqvist U. Adaptation of the Psoriatic Arthritis Quality of Life (PsAQoL) instrument for Sweden. Scand J Rheumatol 2010;39:223-8.

20. Torre-Alonso JC, Gratacós J, Rey-Rey JS, Valdazo de Diego JP, Urriticoechea-Arana A, Daudén E, et al. Development and validation of a new instrument to measure healthrelated quality of life in patients with psoriatic arthritis: the VITACORA-19. J Rheumatol 2014;41:2008-17.

21. Taylor W, Gladman D, Helliwell P, Marchesoni A, Mease P,
Mielants H. Classification criteria for psoriatic arthritis: development of new criteria from a large international study. Arthritis Rheum 2006;54:2665-73.

22. Hunt SM, McKenna SP, McEwen J, Williams J, Papp E. The Nottingham Health Profile: subjective health status and medical consultations. Soc Sci Med A 1981;15:221-9.

23. Kücükdeveci AA, McKenna SP, Kutlay S, Gürsel Y, Whalley $\mathrm{D}$, Arasil T. The development and psychometric assessment of the Turkish version of the Nottingham Health Profile. Int J Rehabil Res 2000;23:31-8.

24. Bruce B, Fries JF. The Health Assessment Questionnaire (HAQ). Clin Exp Rheumatol 2005;23:14-8.

25. Küçükdeveci AA, Sahin $H$, Ataman S, Griffiths B, Tennant A. Issues in cross-cultural validity: example from the adaptation, reliability, and validity testing of a Turkish version of the Stanford Health Assessment Questionnaire. Arthritis Rheum 2004;51:14-9.

26. Gladman DD, Mease PJ, Strand V, Healy P, Helliwell PS, Fitzgerald $\mathrm{O}$, et al. Consensus on a core set of domains for psoriatic arthritis. J Rheumatol 2007;34:1167-70.

27. Gratacós J, Daudén E, Gómez-Reino J, Moreno JC, Casado MÁ, Rodríguez-Valverde V. Health-related quality of life in psoriatic arthritis patients in Spain. Reumatol Clin 2014; 10:25-31.

28. Streiner DL, Norman GR. Health measurement scales. New York: Oxford University Press; 1989.

29. Fleiss JL, Shrout PE. The effects of measurement errors on some multivariate procedures. Am J Public Health 1977;67:1188-91.

30. DeCoster J. Overview of Factor Analysis. 1998. Available from: http://www.stathelp.com/notes.html

\section{Appendix}

VITACORA-19 sorgulamasının geçerliliği yapılmıș versiyonu. Aşağıdaki ifadeler, psöriatik artritin belirti ve bulgularının sizin günlük yaşamınızı nasıl etkilediğinden bahsetmektedir. Sizin cevaplarınız bizlere, geçen hafta boyunca sizin sağlık durumunuzu ve hastalığınızın sizin günlük yașam aktivitelerinizi gerçekleștirme becerinizi nasıl etkilediğini belirlemede yardımcı olacaktır. Her bir ifadenin ardından 5 olası cevap bulunmaktadır. Lütfen her bir ifadeyi dikkatli okuyunuz, her soruyu cevaplayınız. Eğer emin değilseniz, lütfen size doğru gelen en uygun cevabı seçiniz. Cevaplar ne doğru ne de yanlıştır. Biz sadece hastalığınızın sizin günlük yaşamınızı nasıl etkilediŏi ile ilgileniyoruz.

Geçen hafta boyunca, psöriatik artritiniz nedeniyle...

1. Hareket kısıtlılığı hayatımı etkiliyordu.

2. Herhangi bir fiziksel efor sonrası düzelmek uzun zamanımı alır.

3. Yatakta pozisyonumu değiștirmek zordu (örn: dönmek).

4. Fiziksel gücüm azaldı.

5. Motivasyonsuzdum, hiçbir şey yapmak istemeyen durumdaydım.

6. Aşırı yorgun olduğum için üzgün ve mutsuzdum.

7. Hastalığımın yol açtığı ağrı nedeniyle duygu durumum etkilendi.

8. Ağrıdan korkuyordum.

9. Belirti ve bulgular nedeniyle üçüncü şahıslara bağımlı olmaktan dolayı endişeleniyordum.

10. Ağrı bulgularım nedeniyle umutsuzluğa kapıldım.

11. İnsanlarla görüşmekten kaçınıyorum, onlara ayak uyduramıyorum

12. Her zamanki iş/iş-dışı aktivitelerinde (ev işi dahil) performansım azaldı.

13. Hastalıktan dolayı aldığım raporlar nedeniyle işimi kaybetmekten korkuyordum.

14. Cilt görünümüm nedeniyle insanlar benden kaçıyordu.

15. Elle yapılan aktiviteleri gerçekleştirmede (örn: bir şeyi kavramak, sürmek, pişirmek, bilgisayar kullanmak...) zorlanıyordum.

16. Ağrım gecenin ortasında beni uyandırıyor, dinlenmeme izin vermiyordu.

17. Beni en çok ağrı etkiliyordu.

18. Beni en çok iltihap ve eklem rahatsızlığı (örn: ayak bileği, diz, el bileği, parmaklar..) etkiliyordu.

19. Hastalığımın gelecekte ilerlemesinden (baston veya koltuk değneği ihtiyacı..) dolayı endişeleniyordum.

$\begin{array}{ccccc}\text { Daima } & \text { Çok sik } & \text { Bazen } & \text { Nadir } & \text { Asla } \\ 1 & 2 & 3 & 4 & 5 \\ 1 & 2 & 3 & 4 & 5 \\ 1 & 2 & 3 & 4 & 5 \\ 1 & 2 & 3 & 4 & 5 \\ 1 & 2 & 3 & 4 & 5 \\ 1 & 2 & 3 & 4 & 5 \\ 1 & 2 & 3 & 4 & 5 \\ 1 & 2 & 3 & 4 & 5 \\ 1 & 2 & 3 & 4 & 5 \\ 1 & 2 & 3 & 4 & 5 \\ 1 & 2 & 3 & 4 & 5 \\ 1 & 2 & 3 & 4 & 5 \\ 1 & 2 & 3 & 4 & 5 \\ 1 & 2 & 3 & 4 & 5 \\ 1 & 2 & 3 & 4 & 5 \\ 1 & 2 & 3 & 4 & 5 \\ 1 & 2 & 3 & 4 & 5 \\ 1 & 2 & 3 & 4 & 5\end{array}$

